\begin{tabular}{|c|c|c|c|c|}
\hline JURNAL & \multirow{2}{*}{ VOLUME 2} & NOMOR 1 & HALAMAN 1-73 & $\begin{array}{l}\text { ISSN 2655-8823 }(p) \\
\text { ISSN 2656-1786 }(e)\end{array}$ \\
KOLABORASI RESOLUSI KONFLIK
\end{tabular}

\title{
STUDI TENTANG KONFLIK ANTAR PERGURUAN SILAT PSHT DAN IKSPI-KERA SAKTI DI DESA SUMURAGUNG KABUPATEN BOJONEGORO
}

\author{
Muhammad Zakaria \\ Prodi Pendidikan Ilmu Pengetahuan Sosial, Fakultas Ilmu Sosial, Universitas Negeri Malang \\ E-mail: muhammadzakaria1986@gmail.com
}

\begin{abstract}
ABSTRAK
Pencak silat merupakan seni bela diri tradisional yang berasal dari Indonesia. Setiap daerah memiliki berbagai aliran bela diri pencak silat. Termasuk seni bela diri yang terkenal di Bojonegoro yaitu Perguruan silat PSHT dan IKSPI Kera Sakti. Kedua perguruan silat yang berada di Desa Sumuragung, Kec. Baureno, Kab. Bojonegoro ini sering terlibat konflik sehingga menimbulkan kerugian dari segi materill hingga menimbulkan korban jiwa. Bedasarkan latar belakang diatas maka fokus yang ditetapkan oleh peneliti adalah "Konflik Antar Perguruan Silat Di Desa Sumuragung, Kecamatan Baureno, Kabupaten Bojonegoro (Studi Pada Perguran Silat PSHT dan IKSPI Kera Sakti”. Penelitian ini bertujuan untuk mengetahui dinamika konflik antar perguruan PSHT dan IKSPI Kera Sakti di Desa Sumuragung, Kec. Baureno, Kab. Bojonegoro. Penelitian ini merupakan penelitian yang menggunakan metode kualitatif dengan jenis penelitian deskriptif. Subjek penelitian ini di fokuskan kepada anggota perguruan PSHT dan IKSPI Kera Sakti Ranting Sumuragung, warga perguruan, dan sesepuh perguruan silat dari perguruan PSHT dan IKSPI Kera Sakti. Teknik pemilihan informan dengan menggunakan purposive. Dalam melakukan pengumpulan data yaitu dengan menggunakan observasi, wawancara, dan studi dokumen. Bedasarkan hasil penelitian diketahui bahwa konflik antar perguruan silat PSHT dan IKSPI Kera Sakti di Desa Sumuragung merupakan tindakan dari oknum anggota perguruan silat yang mengatasnamakan perguruan dan melibatkan kelompok perguruan. Sifat kompetisi dan saling eksistensi yang dimiliki antar anggota perguruan ini menimbulkan konflik antar kedua perguruan, sehingga permasalahan sepele nisa memicu konflik yang menjadi besar. Konflik antar kedua perguruan ini tidak hanya menimbulkan kerugian bagi anggota perguruan yang terlibat, tetapi juga membawa kerugian bagi Perguruan Silat.
\end{abstract}

Kata Kunci: Konflik, Dinamika Konflik, Perguruan Silat PSHT, dan Perguruan IKSPI Kera Sakti.

\section{PENDAHULUAN}

Pencak silat merupakan bela diri tradisional Indonesia yang berakar dari budaya Melayu, dan bisa ditemukan hampir di seluruh wilayah Indonesia (Gunawan, 2007). Pencak silat di Nusantara sudah ada sejak zaman kerajaan dengan tujuan sebagai dasar pertahanan dan keamanan untuk melindungi kerajaan (Orchid, 2010). Menurut Wahyu (2018) menyatakan bahwa pencak silat tumbuh dan berkembang dari zaman penjajahan turun temurun melalui proses yang panjang ke generasi selanjutnya.

Menurut Orchid (2010) bela diri dalam pencak silat mengandung dua makna yaitu seni dan pembelaan diri. Seni dalam pencak silat merujuk pada keindahan, pola gerak, dan lebih khusus diartikan sebagai seni pertunjukan pencak silat. Pembelaan diri dalam pencak silat diartikan sebagai serang-bela dan bagaimana cara melindungi diri dari lawan. Berbagai bentuk pencak silat di Indonesia bukan hanya sekedar tekhnik untuk membela diri tapi juga aset budaya yang harus dilestarikan. Teknik gerakan pada pencak silat yang diwariskan secara turun temurun tanpa campur tangan budaya barat melambangkan kesakralan dan budaya khas Indonesia (Notosoejitno, 1997). Hal ini dapat disimpulkan bahwa pencak silat merupakan hasil budaya manusia Indonesia yang perlu dilestarikan yang tujuanya untuk membela, mempertahankan, eksistensi (kemandirian) dan integritasnya (manunggal) terhadap lingkungan hidup/alam sekitarnya untuk mencapai keselarasan hidup guna meningkatkan iman dan taqwa (Gristyutawati, 2012). 


\begin{tabular}{|c|c|c|c|c|}
\hline JURNAL & \multirow{2}{*}{ VOLUME 2 } & \multirow{2}{*}{ NOMOR 1 } & HALAMAN 1-73 & $\begin{array}{l}\text { ISSN 2655-8823 }(p) \\
\text { ISSN 2656-1786 }(e)\end{array}$ \\
KOLABORASI RESOLUSI KONFLIK
\end{tabular}

Persaudaraan Setia Hati Terate (PSHT) merupakan salah satu perguruan besar Pencak Silat di Indonesia didirikan oleh Ki Hardjo Oetomo tahun 1922 yang masih berkembang pesat, baik dalam negeri maupun luar negeri (MUBES VI, 2000). Perguruan lain yang masih eksis mempertahankan nilai, tradisi, budaya serta kesakralan adalah IKSPI Kera Sakti (Yulianie, 2015). Kedua perguruan ini bertujuan untuk mendidik manusia berbudi luhur dan ikut serta untuk melestarikan budaya asli Indonesia.

Keberadaan berbagai perguruan silat sebagai kebudayaaan yang perlu dilestarikan dan diwariskan secara turun temurun. Pncak silat mengalami perkembangan waktu dibukjtikan dari semaikn banyaknya perguruan. Namun, banyaknya perguruan silat juga beriringan dengan timbulnya suatu masalah yaitu konflik antar perguruan. Bedasarkan data laporan Polres Kabupaten Bojonegoro pada tahun 2017, terdapat 13 kasus konflik kekerasan yang melibatkan anggota perguruan pencak silat (Laporan Polres, 2014-2017). Kesenjangan dari penelitian ini ialah pencak silat yang seharusnya menjadi kekayaan budaya asli indonesia yang perlu dilestarikan dan dikembangkan akan tetapi timbul suatu penyimpangan yaitu konflik kekerasan (Wawancara dengan Wahyu, 26 Januari 2018).

Konflik pada dasarnya adalah sesuatu yang tidak terhindarkan dalam kehidupan. Menurut Takacs (2002) konflik antar kelompok adalah keinginan individu untuk berkonstribusi terhadap tindakan kelompok dengan merugikan kelompok lain. Konflik antar kelompok timbul karena adanya sejarah persaingan, prasangka dan rasa benci, baik itu sifatnya pribadi, politis, maupun ideologis yang melatar belakanginya (Wirawan, 1999). Dalam hal ini konflik antar perguruan silat yang bersifat individu atau kolektif antara kelompok satu dengan kelompok lainya yang dilatar belakangi oleh perbedaan ideologi, eksistensi, memperluas ajaran/ kekuasaan, perbedaan tujuan dan kepentingan tiap kelompok hingga menyebabkan gesekan dan berakibat konflik (Maksum, 2009).

Dari laporan Polres pada tangal 29 Oktober 2017 menunjukkan bahwa terjadi penganiayaan yang melibatkan anggota pencak silat di Desa Sumuragung, Kec Baureno, Kab. Bojonegoro. Kejadian tersebut dilakukan oleh pemuda yang menggunakan atribut perguruan PSHT terhadap pemuda yang menggunakan atribut IKSPI Kera Sakti. Korban dipukul dibagian kepala belakang dan dibawa ke puskesmas Baureno, sedangkan tersangka masih dalam proses penyeledikan (Laporan Polres, 2017).

Kasus serupa juga terjadi pada tanggal 09 Juli 2016 di desa Sumuragung Kec. Baureno, Kab. Bojonegoro. Kasus pengeroyokan dilakukan oleh sekitar 100 orang beratribut PSHT dan menggunakan cadar. Korban dari pengeroyokan tersebut berjumlah lima orang dan mengalami kerusakan pada kendaraan dan salah seorang rumah. Telah dilaksanakan penilisikan dari Satgas gabungan dan telah ditetapkan sembilan orang anggota PSHT sebagai tersangka (Laporan Polres, 2016).

Resolusi konflik sudah dilaksanakan sebagai upaya meredam konflik antar anggota pencak silat yaitu dengan deklarasi ikrar damai dan diresmikan Bojonegoro Kampung Pesilat oleh Pemkab Bojonegoro pada tanggal 20 agustus 2016 (Lapharsus, 2016). Ditetapkanya peraturan dan resolusi konflik tersebut seolah tak dihiraukan oleh perguruan pencak silat. Konflik tetap terjadi di tahun-tahun selanjutnya pada momentum-momentum tertentu. Bedasarkan latar belakang yang telah dikemukakan, maka rumusan masalah penelitian ini adalah bagaimana Dinamika Konflik antar Perguruan PSHT dan IKSPI Kera Sakti di Desa Sumuragung Kecamatan Baureno Kabupaten Bojonegoro? 


\begin{tabular}{|c|c|c|c|c|}
\hline JURNAL & \multirow{2}{*}{ VOLUME 2} & \multirow{2}{*}{ NOMOR 1 } & HALAMAN 1-73 & $\begin{array}{l}\text { ISSN 2655-8823 }(p) \\
\text { ISSN 2656-1786 }(e)\end{array}$ \\
\hline
\end{tabular}

KAJIAN PUSTAKA

\section{Kajian Pusataka tentang Konflik}

Konflik merupakan gejala sosial yang hadir didalam kehidupan sosial, sehingga konflik memiliki sifat inheren, yaitu terjadi dimanapun, kapanpun, dan tanpa sebab yang tanpa diduga yang ada dalam ruang dan waktu. Dalam setiap konflik ada beberapa diantaranya yang dapat diselesaikan, tetapi ada juga yang tidak dapat terselesaikan hingga menuju ke arah kekerasan. Kekerasan timbul dari gejala konflik yang tidak dapat teratasi. Model dari kekerasan bermacam-macam mulai dari kekerasan kecil hingga terjadi perperangan.

Istilah konflik secara etimologis berasal dari bahasa Latin "con" yang berarti bersama dan "figure" yang berarti berbenturan atau bertabrakan. Menurut Soerjono Soekanto (2013) Konflik artinya percekcokan, perselisihan, dan pertentangan.

Pruit dan Rubbin mendefinisikan konflik sebagai sebuah persepsi mengenai perbedaan kepentingan, atau suatu kepercayaan yang beranggapan bahwa aspirasi pihak-pihak yang berkonflik tideak dapat menemui titik temu yang sepaham. Dari pengertian diatas peneliti simpulkan bahwa konflik sosial adalah proses interaksi salah satu pihak dengan pihak lain di masyarakat yang ditandai dengan sikap saling mengancam, menekan, hingga menghancurkan.

\section{Kajian Pusataka Tentang Teori Dinamika Konflik}

Melihat dinamika konflik adalah dengan melihat sumber konflik, yaitu segala sesuatu yang menjadi inti masalah. Kemudian perlu melihat karakter hubungan diantara berbagai pihak yang terlibat konflik.

Menurut Fisher tahapan dinamika konflik meliputi prakonflik, konfrontasi, krisis, dan pasca konflik (Fisher, 2001):

1. Pra Konflik adalah periode pada saat terdapat suatu ketidaksesuaiaan sasaran diantara dua pihak atau lebih, sehingga timbul konflik. Konflik tersembunyi dari pandanan umum, meskipun satu pihak atau lebih mengetahui potensi terjadinya konfrontasi

2. Konfrontasi adalah memperlihatkan suatu tahap pada saat konflik mulai terbuka. Jika hanya salah satu pihak yang merasa ada masalah, mungkin para pendukungnnya mulai melakukan aksi demonstrasi atau melakukan aksi konfrontasi lainya.

3. Krisis adalah puncak dari konflik. Tahap ketika konflik pecah menjadi bentuk aksi-aksi kekerasan yang dilakukan secara intens dan massal. Sebagai wujud dari tahap krisis konflik yaitu konflik yang terjadi dalam skala besar dan sudah ada pihak yang terbunuh.

4. Pasca Konflik yaitu suatu situasi dimana ketegangan sudah berkurang, konfrontasi kekerasan sudah diselesaikan, dan hubungan para pihak yang bertikai sudah mengarah normal kembali.

Sementara itu dalam mengetahui jenis konflik (Fisher, 2001) dibedakan menjadi dua bagian, antara lain:

1. Konflik Vertikal yaitu konflik yang terjadi antara elite dalam hal ini pemerintah.

2. Konflik horizontak yaitu konflik yang terjadi dalam kalangan masyarakat sendiri.

Untuk membedakan tipe konflik (Fisher, 2001) terdapat beberapa kondisi dimana akan membantu peneliti untuk mendapat dinamikan konflik yang sesuai, Tipe-tipe konflik tersebut meliputi (1) konflik laten adalah suatu keadaan yang di dalamnya terdapat persoalan, tetapi sifatnya tersembunyi, dan hal ini perlu diangkat ke permukaan agar segera ditangani dengan baik (2) konflik terbuka adalah suatu keadaan ketika konflik sosial telah muncul di permukaan, yang berakar dalam, dan sangat nyata, sehingga 


\begin{tabular}{|c|c|c|c|c|}
\hline JURNAL & \multirow{2}{*}{ VOLUME 2} & \multirow{2}{*}{ NOMOR 1 } & HALAMAN 1-73 & $\begin{array}{l}\text { ISSN 2655-8823 }(p) \\
\text { ISSN 2656-1786 }(e)\end{array}$ \\
\hline
\end{tabular}

diperlukan tindakan khusus untuk mengartasi akar masalah dan efeknya (3) konflik permukaan yaitu suatu kondisi yang memiliki akal dangkal dan muncul karena kesalah pahaman yang dapat diatasi melalui komunikasi atau dialog terbuka.

\section{METODE PENELITIAN}

Penelitian ini menggunakan pendekatan penelitian kualitatif dengan jenis penelitian deskriptif. Penelitian kualitatif digunakan sebagai pendekatan dalam mendeskripsikan konflik antar Perguruan PSHT dan IKSPI Kera Sakti, faktor penyebab terjadinya konflik antar perguruan PSHT dan IKSPI Kera Sakti di Desa Sumuragung, beserta dampak dari terjadinya konflik antar perguruan PSHT dan IKSPI Kera Sakti. Jenis dan sumber data adalah mengenai dari mana data diperoleh. Data diperoleh dari pengambilan sumber langsung (data primer) dan pengumpulan sumber tidak langsung (data sekunder). Pada penilitian ini, peneliti menggunakan beberapa teknik pengumpulan data untuk menjaga keakuratan data yang diterima. Adapun beberapa teknik tersebut yaitu wawancara, observasi dan studi dokumentasi. Penelitian ini menggunakan analisis interaktif dari Miles \& Huberman (2014) peneliti berperan sebagai informan kunci yang turut langsung terjun ke lapangan untuk ambil data, olah data, analisis data, dan penyajian data. Lokasi penelitian ini pada Perguruan PSHT Ranting Sumuragung, dan Perguruan IKSPI Kera Sakti Ranting Sumuragung, berada di Desa Sumuragung, Kecamatan Baureno, Kabupaten Bojonegoro.

\section{PEMBAHASAN}

\section{Deskripsi Konflik Antar Perguruan}

Konflik antar perguruan di Desa Sumuragung, Kec. Bojonegoro, Kab. Bojonegoro merupakan tindakan dari oknum anggota silat yang tidak bertanggung jawab. Konfik antar perguruan timbul pada saat perguruan berbeda saling bertemu dalam kegiatan dimana anggota silat membawa atribut perguruannya masing-masing. Dalam hal ini, konflik antar perguruan diawali dengan permasalahan pribadi dan mengatasnamakan perguruan, sehingga bukan atas kewenangan perguruan silak. Konflik tersebut sifatnya turun-temurun dan puncaknya terjadi pada tahun 2013 hingga tahun 2017 (data polres, 2017).

\section{Faktor Penyebab Terjadinya Konflik Antar Perguruan}

Faktor penyebab terjadinya konflik antar perguruan silat di Desa Sumuragung, Kec. Baureno, Kab. Bojonegoro dikarenakan banyaknya anggota dibawah umur (15th-18th) yang telah disahkan menjadi warga. Anggota silat yang masih muda menggunakan emosional dan sifat tempramental untuk menyelesaikan suatu masalah. Masalah dalam perguruan silat diawali dengan permasalahan individu yang meluas ke anggota yang lain karena sifat persaudaraan antar anggota. Anggota yang terlibat konflik disebabkan karena penyalahgunakan ajaran yang digunakan untuk kepentingan individu. Penyalahgunaan ajaran pada anggota juga disebabkan dari minimnya pendidikan karakter yang diajarkan oleh perguruan. Pencak silat hanya ditekankan pada pendidikan bela diri dan fisik

\section{Dampak Terjadinya Konflik Antar Perguruan}

Hadirnya konflik antar perguruan silat memberikan dampak bagi pelaku maupun masyarakat. Dampak tersebut menyebabkan konflik akan semakin meluas dan akan timbul konflik perguruan di daerah lain. Konflik yang semakin besar akan memiliki peluang bagi anggota yang terlibat untuk terjerat masalah hukum perihal kekerasan, penganiayaan dan tindakan pengeroyokan. Anggota silat yang terjerat masalah hukum, selain akan mengancam masa depan juga akan dibatasi oleh lingkungan terdekat untuk mengikuti pencak silat, selain itu anggota yang terlibat konflik akan dikeluarkan dari 


\begin{tabular}{|c|c|c|c|c|}
\hline JURNAL & \multirow{2}{*}{ VOLUME 2 } & \multirow{2}{*}{ NOMOR 1 } & HALAMAN 1-73 & $\begin{array}{l}\text { ISSN 2655-8823 }(p) \\
\text { ISSN 2656-1786 }(e)\end{array}$ \\
\hline
\end{tabular}

perguruan secara tidak hormat. Dampak dari adanya konflik juga dirasakan perguruan yang berakibat pada hubungan baik ke sesama perguruan silat. Perguruan silat terlibat mendapat citra negatif dari masyarakat dan media massa. Selain itu, masyarakat juga mengalami dampak mulai dari kerugian materi dan non materi sampai timbulnya korban jiwa

\section{Kontrol Sosial dari Perguruan Silat dalam Meminimalisir Terjadinya Konflik}

Perguruan silat memiliki nilai dan norma yang berlaku. Penanaman niat dan tujuan kepada anggota menjadi dasar agar menjalankan ajaran dengan baik. Akan tetapi minimnya pemberian materi kerohanian, pendidikan karakter, dan pendalaman budi pekerti luhur pada latihan sehari hari mempengaruhi pemahaman anggota mengenai tujuan dan prinsip dari seorang pendekar, sehingga mudah dalam terlibat konflik. Tindakan perguruan dalam meminimalisir terjadinya konflik terhadap anggota dalam bentuk sidang; himbauan; dan pengeluaran anggota.

\section{KESIMPULAN DAN SARAN Kesimpulan}

Bedasarkan hasil penelitian dan pembahasan yang peneliti temukan dapat disimpulkan: Konflik antara perguruan PSHT dan IKSPI Kera Sakti di Desa Sumuragung, Kec. Baureno, Kab. Bojonegoro merupakan tindakan oknum. Oknum dalam hal ini adalah individuindividu yang menjdai anggota perguruan silat tetapi menyalahgunakan ajaran untuk konflik. Konflik antar anggota terjadi pada kegiatan yang mempertemukan dua perguruan. Konflik ini disebabkan oleh perbedaan ideologi perguruan silat; pemahaman yang kurang mengenai ajaran dan tujuan perguruan; perbedaan identitas perguruan; rasa solidaritas antar anggota perguruan tinggi; dan mudahnya anggota terprovokasi oleh perguruan lain. Konflik antara anggota silat tersebut memberikan dampak pada peran perguruan dalam menanggapi terjadinya konflik antar perguruan silat, tindakan yang pencegahan perguruan untuk anggota dalam bentuk pemberian nasihat; pembentukan karakter; melibatkan anggota dalam kejuaraan; melakukan rapat rutin koordinasi organisasi; dan melibatkan angota terlibat kegiatan BKP sebagai upaya mencegah terjadinya konflik perguruan. Tindakan penanganan perguruan untuk anggota dalam bentuk penegakan sanksi-sanksi; musyawarah pengurus organisasi; rapat koordinasi BKP sebagai upaya meminimalisir terjadinya konflik perguruan.

\section{Saran}

Bagi penelitian selanjutnya, sebaiknya peneliti dapat melakukan penelitian dengan amatan tambahan penelitian mengenai peran pemerintah dalam menanggapi konflik antar perguruan silat di Kab. Bojonegoro. Bagi perguruan pencak silat, sebaiknya meninjau ulang peraturan dan norma yang diterapkan dalam menangapi anggota yang terlibat konflik. Tahap pengendalian sosial dari pemberian hukuman fisik, himbauan atau nasihat dan yang terakhir pengeluaran anggota secara paksa dinilai tidak efektif $\&$ efesien. Hal tersebut dikarenakan konflik tetap terjadi lagi pada kegiatan selanjutrnya. Sebaikanya perguruan silat berperan aktif dalam tindakan pencegahan seperti melibatkan anggota perguruan dalam kegiatan Bojonegoro Kampung Pesilat; melibatkan anggota perguruan pencak silat dalam kejuaraan pencak silat; dan pembentukan karakter setiap anggota dengan cara meningkatkan penanaman nilai dan norma pada anggota perguruan pada tiap kegiatan belajar pencak. Bagi anggota perguruan, berlatih pencak silat secara utuh dengan cara memahami ajaran; menerapkan ajaran secara baik dan benar dalam kehidupan sehari-hari; dan mampu menerima informasi secara utuh yang berkenaan dengan pencak silat. 


\begin{tabular}{|c|c|c|c|c|}
\hline JURNAL & \multirow{2}{*}{ VOLUME 2 } & \multirow{2}{*}{ NOMOR 1 } & HALAMAN 1-73 & $\begin{array}{l}\text { ISSN 2655-8823 }(p) \\
\text { ISSN 2656-1786 }(e)\end{array}$ \\
KOLABORASI RESOLUSI KONFLIK & HOLA
\end{tabular}

\section{DAFTAR PUSTAKA}

Fisher, Simon, dkk. 2001. Mengelola Konflik: Ketrampilan \& Strategi Untuk Bertindak. Jakarta: The British Council.

Gunawan, G.A. 2007. Beladiri. Yogyakarta: Pustaka Insan Madani.

Miles, Metthew B. \& Huberman A. Michael. 1992. Analisis Data Kualitatif (Buku Sumber Tentang Metode Metode Baru). Terjemahan Tjejep Rohendi Rohidi. Jakarta: UIPress.

Mulyana, Agus. 2016. Pencak Silat Setia Hati, Sejarah, Filosofi, Adat Istiadat. Bandung: Tulus Pustaka.

Novri, Susan, 2009, Pengantar Sosiologi Konflik dan Isu-isu Konflik Kontenporer. Jakarta.

Prutt, D. G, \& Rubbin, Z. 2004. Teori Konflik Sosial. Cetakan Pertama, Yogyakarta: Pustaka Belajar.

Gristyutawati, Dkk. 2012. Persepsi Pelajar Terhadap Pencak Silat Sebagai Warisan Budaya Bangsa Sekota Semarang Tahun 2012. 1(3). Journal of Physical Education, Sport, Health and Recreation. (Online). Diakses tanggal 19 September 2017.

Gustiana, Satria R. 2013. Kajian Kriminologi Terhadap Faktor Penyebab Terjadinya Konflik Antar Anggota Perguruan Pencak Silat (Studi di Persaudaraan Setia Hati Tunas Muda Winongo dan Persaudaraan Setia Hati Terate serta Kepolisian Resort Kota Madiun). The Indonesian Journal of Criminology. (Online). Diakses tanggal 05 Januari 2018.

Maksum, Ali. 2009. Konflik Kekerasan Antar Kelompok Perguruan Silat: Proses Pembentukan Sosial Yang Terdistorsi. 24(2). Indonesian Psychological Journal. (Online) Diakses tanggal 28 Januari 2016.

Muzakky, I. 2015. Kebangan Kolektif Anggota Perguruan Silat (Kera Sakti, Setia Hati, Pagar Nusa). Skripsi. Malang: UIN Maulana Malik Ibrahim.
Nasution. 2011. Kajian Pembelajaran IPS di Sekolah. Surabaya: Unesa University Press.

Yulianie, Diahayu. 2015. Tradisi Konflik Perguruan Silat Setia Hati (Studi Kasus Perguruan Silat Setia Hati Terate dengan Setia Hati Winongo di Kabupaten Madiun). Skripsi. Diakses tanggal 09 Oktober 2017. 